[Radiocarbon, Vol. 12, No. 2, 1970, P. 590-598]

\title{
UNIVERSITY OF CAMBRIDGE NATURAL RADIOCARBON MEASUREMENTS IX
}

\author{
V. R. SWITSUR, M. A. HALL, and R. G. WEST \\ Sub-Department of Quaternary Research \\ 5 Salisbury Villas, Station Road, Cambridge
}

The University of Cambridge Radiocarbon Dating Laboratory has been completely rebuilt and modernized, incorporating new techniques developed here for the various stages of measurements. Sample radioactivity is measured in gas proportional counters after conversion to highly purified $\mathrm{CO}_{2}$. Four counters are mounted within a single anticoincidence shield consisting of plastic scintillation material. This is surrounded by a graded cosmic ray shield of low radioactive steel, boron loaded wax, and finally, about 16 tons of ancient low radioactive lead blocks. The electronics are all solid state devices except for the stabilized high voltage supplies.

A large plastic anticoincidence shield, in which it is possible to place several proportional counters of differing sizes, has been developed and functions well. It is $105 \mathrm{~cm}$ long and $40 \mathrm{~cm}$ in diameter with minimum wall thickness of $7.5 \mathrm{~cm}$ at any point; it completely encloses the sample counters with scintillation material so that even axial radiation is detected. Cosmic-ray produced charged particles are detected with $100 \%$ efficiency and the shield has high efficiencies for $\gamma$-rays and neutrons. It gives better shielding than the normal Geiger or multiple anode anticoincidence shields since their detection efficiencies for uncharged particles are relatively low. Scintillations are detected by two $25 \mathrm{~cm}$ diameter photomultiplier tubes operating in coincidence, to reduce noise, and the resultant pulses are used in anticoincidence with the pulses from the sample counters.

Pure copper is used for the proportional counter bodies; two have tin oxide coated quartz inner liners to which the E.H.T. is applied. They are normally operated at 2 atm pressure of $\mathrm{CO}_{2}$. Plateaux at least 1200 volts long with slopes of $0.4 \%$ per 100 volts are routinely typical of the 2 counters that are at present used for dating purposes.

All samples are subjected to pretreatment, unless otherwise stated, to attempt to remove contamination due to carbon non-contemporary with the sample. Pretreatment consists of boiling the shredded sample with $1 \%$ hydrochloric acid solution for at least $1 \mathrm{hr}$ and a similar treatment with $1 \%$ solium hydroxide solution. Following each of these reagents, the sample is boiled with distilled water, finally filtered and dried, either at $110^{\circ} \mathrm{C}$ or in the vacuum oven.

Oxidation of the samples is carried out very rapidly and efficiently with high pressure oxygen in a specially developed combustion bomb. This consists of a 5L stainless steel cylinder with a gas-tight lid carrying inlet and outlet tubes for the gases and held in position with a spin ring. Our experiments have shown that small volume, higher pressure 
bombs are not as effective, as the combustion flame is quenched and material remains unburned. Samples of $20 \mathrm{~g}$ are easily combusted with $8 \mathrm{~atm}$ pressure of oxygen when an electric current is passed through a thin wire covered by the sample held in a quartz or nickel crucible. The reaction is over within a few seconds as shown by the pressure gauge returning to its original reading. The great heat dissipated is removed rapidly by an external jacket with a flow of cooling water.

Boiled water placed in the combustion bomb removes most of the sulphur and nitrogen oxides from the reaction products and the $\mathrm{CO}_{2}$ may easily be purified to the stringent requirements for proportional counting. The purification line contains all dry reagents operating under reduced pressure; it is semi-automatic and requires little attention during the hour or so taken from the initial firing of the combustion bomb to the production of a fairly pure sample of solid $\mathrm{CO}_{2}$. A final purification line consisting of several in vacuo distillations through furnaces containing finely divided copper catalyst on a silica/alumina support and silver metal yield the pure counting gas.

The pulses from the anticoincidence shield and each counter are amplified and passed through pulse-height analyzers prior to being counted on fast scalers. Separate scalers also record the selected anticoincidence, i.e., radiocarbon, pulses for each channel. Accumulated counts and the time required in minutes are printed out at pre-set intervals on a teletypewriter which can also produce punched paper tape for computer use. Experiments are normally conducted overnight for $1000 \mathrm{~min}$ and throughout the weekend. Usually sufficient runs are made on each sample to accumulate at least 10,000 disintegrations above background so that the statistical uncertaintly is reduced to $<1 \%$. The laboratory modern standard is the activity of the 1850 growth ring of oak tree grown in the Cambridgeshire Fens and this is compared with $95.0 \%$ of the activity of the N.B.S. oxalic acid. The background is that given by a sample of Welsh Anthracite. The ages of samples are calculated using the conventional half life of $5568 \pm 30$ years and the uncertainty is stated in terms of one standard deviation of the counting statistics.

A full description of the laboratory and processes used is in preparation for publication elsewhere.

The dating program of the new laboratory is maintaining the policy of directing assays largely toward projects under investigation in the University Sub-Department of Quaternary Research. In 1969 these projects included dating of pollen zone boundaries, of Scottish tree stump horizons, and of archaeologic sequences in the Somerset levels.

\section{ACKNOWLEDGMENTS}

It is with pleasure that we acknowledge the encouragement and advice of $\mathrm{H}$. Godwin during the rebuilding of the laboratory, as well as the practical help of colleagues N. J. Shackleton and G. A. Sutton, whose post of Technical Asst. was recently filled by M. A. Hall. Mr. Hall 
has carried a large proportion of the work in the final setting up and testing of the equipment. Our thanks are given to A. P. Ward and C. Devine who now share the task of maintaining the standards of the laboratory.

Financial support for the development projects in the laboratory has been provided by the Science Research Council and the Natural Environmental Research Council to whom we express our thanks.

\section{SAMPLE DESCRIPTIONS}

\section{GEOLOGIC SAMPLES}

\section{British Isles}

\section{Pollen Zone Boundary Determinations (Red Moss) series}

The vertical sequence through a raised bog, Red Moss near Horwich, Lancashire $\left(53^{\circ} 35^{\prime} \mathrm{N}\right.$ Lat, $2^{\circ} 35^{\prime} \mathrm{W}$ Long, Nat. Grid. Ref. SJ 631103) has been subjected to careful pollen analysis. A monolith of peat was transferred to the laboratory and each major zone boundary was identified and marked. Two or three peat samples were taken as thin slices at each boundary and at intermediate points corresponding to significant changes in the pollen diagram. These were carefully pretreated to remove contaminants and combusted in pure oxygen. They extend from Zone III of the Late-Weichselian period to Zone VIIb of the Flandrian. The results are discussed in detail by Hibbert and Switsur (ms. in preparation). Collection and pollen analysis are by F. A. Hibbert and radiocarbon measurements by V. R. Switsur. The pollen zones are those currently in use in England and Wales.

The results from the site, apart from the lowest sample, are internally consistent and comparable with those obtained at Scaleby Moss (Godwin, Walker, and Willis, 1957).

The separate samples are identified by depth in the pollen diagram.

Q-910. Red Moss, 114 to $116 \mathrm{~cm}$

$4370 \pm 80$

$2 \mathrm{~cm}$ slice of Sphagnum-Eriophorum-Calluna peat Pollen curves at this level show recovery in Ulmus and Tilia with a fall in weeds and grass pollen, possibly indicating the end of a Landnam occupation phase.

Q-911. Red Moss, 124 to $126 \mathrm{~cm}$

$4715 \pm 80$

$2 \mathrm{~cm}$ slice of Sphagnum-Eriophorum-Calluna peat. Pollen diagrams show Ulmus at very low frequency but the weed pollen is high, possibly indicating a Landnam occupation.

\section{Q-912. Red Moss, 132 to $134 \mathrm{~cm}$}

$2 \mathrm{~cm}$ slice of moderately humified Sphagnum-Eriophorum-Calluna peat. The pollen diagram here indicates boundary of Zone VIIa/VIIb; Ulmus pollen falls to very low frequencies here. 
Q-913. Red Moss, 139 to $140 \mathrm{~cm}$

$5060 \pm 80$

$2 \mathrm{~cm}$ slice of Sphagnum-Eriophorum-Calluna peat. Pollen diagram indicates close of Zone VIIa by beginning of decline of Ulmus pollen frequencies.

\section{Q-914. Red Moss, 158 to $160 \mathrm{~cm}$}

$5399 \pm 100$ 3449 B.c.

$2 \mathrm{~cm}$ slice of Sphagnum-Eriophorum-Calluna peat. Pollen curves for Fraxinus and Tilia exhibit maxima here.

\section{Q-915. Red Moss, 225 to $227 \mathrm{~cm}$}

$6880 \pm 100$

$2 \mathrm{~cm}$ slice of Sphagnum-Eriophorum-Calluna peat. Pollen curves for Fraxinus and Tilia begin here and rapid expansion of Alnus ends.

\section{Q-916. Red Moss, 230 to $232 \mathrm{~cm}$}

$7107 \pm 120$

$2 \mathrm{~cm}$ slice of Sphagnum-Eriophorum-Calluna peat. There is a very rapid rise of Alnus pollen frequencies in the diagram here indicating boundary of Zones VI/VIIa, generally recognized as Boreal/Atlantic transition.

Q-917. Red Moss, 237 to $239 \mathrm{~cm}$

$7460 \pm 150$

$2 \mathrm{~cm}$ slice of Sphagnum-Eriophorum-Calluna peat. The pollen diagram shows the beginning of the rise in Alnus pollen marking the end of Zone VI.

Q-918. Red Moss, 259 to $261 \mathrm{~cm}$

$8196 \pm 150$

$2 \mathrm{~cm}$ slice of fen peat. Pollen frequencies of Pinus exceed those of Betula. This increase is before the Alnus rise.

Q-919. Red Moss, 269 to $271 \mathrm{~cm}$

$8742 \pm 170$

6793 в.c.

$2 \mathrm{~cm}$ slice of wood peat. At a level of falling pollen frequencies of Corylus and rising frequencies of Ulmus and Quercus.

Q-920. Red Moss, 290 to $293 \mathrm{~cm}$

$8790 \pm 170$

$2 \mathrm{~cm}$ slice of wood peat. At level where rapid rise of Corylus pollen frequencies in a very short depth denotes Zone V/VI boundary.

Q-921. Red Moss, 296 to $298 \mathrm{~cm}$

$8880 \pm 170$

$2 \mathrm{~cm}$ slice of wood peat. Pollen diagram indicates the beginning of the rise of Corylus at this level, denoting the end of Zone V.

Q-922. Red Moss, 305 to $307 \mathrm{~cm}$

$9456 \pm 200$

$2 \mathrm{~cm}$ slice of fen peat. Betula pollen frequencies increase at Zone IV/V boundary. 
Q-923. Red Moss, 310 to $312 \mathrm{~cm}$

$2 \mathrm{~cm}$ slice of fen peat. At this point the curve of Juniperus is falling, indicating end of Zone IV.

Q-924. Red Moss, 320 to $322 \mathrm{~cm}$

$9798 \pm 200$

7848 B.c.

$2 \mathrm{~cm}$ slice of fen peat. Pollen diagram shows maximum frequencies of Juniperus pollen in Zone IV.

\section{Q-925. Red Moss, 325 to $330 \mathrm{~cm}$}

$9508 \pm 200$

$5 \mathrm{~cm}$ slice of organic lake mud, immediately above clay deposits of Zone III and marks the beginning of organic deposition at Zone III/IV boundary. Age of this sample does not fit the excellent consistency of the remainder of the series. An identical sample from a duplicate core yielded the same results for age. The sample is at the contact of clay and mud. Perhaps the lateral movement of ground water along such a contact has introduced younger carbon into the mud. Further investigations are required for this point.

\section{Scottish Tree Stump series}

Part of an investigation of the stratigraphy of horizons of tree stumps commonly found in Scottish peats (Birks, 1969). Samples were gathered from 2 main areas, the Eastern Highlands and the Galloway Hills in SW Scotland. Three sites were studied by Lewis $(1905-7,1911)$ who described forest and arctic plant beds in the Merrick-Kells dist. and the Eastern Highlands. Samuelson (1910) correlated Scandinavian tree layers with those in Scotland and applied the climatic sequence of Blytt and Sernander to the British Isles. Samples for pollen analysis and radiocarbon assay were coll. 1965 and 1966 by H. H. Birks and radiocarbon assays were made by V. R. Switsur.

\section{Eastern Highland area}

Q-886. Allt na Feithe Sheilich

$4425 \pm 100$ 2475 B.C.

Birch and heather twigs form indistinct horizon at $150 \mathrm{~cm}$, probably indicating a dry period on peat surface. Pine wood from an horizon $180 \mathrm{~cm}$ below surface was previously dated (K-1419, $6960 \pm 130$ B.P.). This is one of original Lewis sites of blanket peat on the Spey-Findhorn watershed at $1950 \mathrm{ft}$ alt $\left(57^{\circ} 19^{\prime} \mathrm{N}\right.$ Lat, $3^{\circ} 54^{\prime} \mathrm{W}$ Long, Nat. Grid Ref. 28/8526).

\section{Q-881. Loch Einich, $120 \mathrm{~cm}$}

$5880 \pm 100$ 3930 в.c.

Fossil mor humus 'soil' at $120 \mathrm{~cm}$ forming a stratigraphic horizon between the pine stumps at this site. Alt $1650 \mathrm{ft}\left(57^{\circ} 05^{\prime} \mathrm{N}\right.$ Lat, $3^{\circ} 48^{\prime}$ W Long, Nat. Grid Ref. 28/919001). Pine stump from this layer was previously dated (K-1418, $5970 \pm 120$ B.P.). 
Q-883. Loch Einich, $80 \mathrm{~cm}$

$4150 \pm 100$

Birch twigs from $80 \mathrm{~cm}$ layer.

2200 B.C.

Q-887. Coire Bog, $255 \mathrm{~cm}$

$6980 \pm 100$

5030 в.c.

Bark from pine stump at $255 \mathrm{~cm}$ assoc. with ill-defined charcoal layer above Sphagnum peat at $215 \mathrm{~cm}$. Alt $1400 \mathrm{ft}\left(57^{\circ} 51^{\prime} \mathrm{N}\right.$ Lat, $4^{\circ} 25^{\prime}$ W Long, Nat. Grid. Ref. 28/582857).

Q-888. Coire Bog, $190 \mathrm{~cm}$

$6731 \pm 100$

Birch wood from $190 \mathrm{~cm}$ depth contained in humified peat.

4781 B.c.

Q-889. Coire Bog, $160 \mathrm{~cm}$

$5005 \pm 100$

Birch wood from $160 \mathrm{~cm}$ depth, a separate layer from that at $190 \mathrm{~cm}$.

\section{Galloway area}

Q-871. Cooran Lane, $110 \mathrm{~cm}$

$7471 \pm 120$

5521 B.c.

Pine stump from decayed, highly humified, blanket-bog peat at depth $110 \mathrm{~cm}$. Alt $850 \mathrm{ft}\left(55^{\circ} 7^{\prime} \mathrm{N}\right.$ Lat, $4^{\circ} 23^{\prime} \mathrm{W}$ Long, Nat. Grid. Ref. 25/ 480843).

Q-873. Cooran Lane, $120 \mathrm{~cm}$

$6805 \pm 200$

Blanket-bog peat from $120 \mathrm{~cm}$ corresponding to peak of Pinus pollen in pollen diagram.

Q-874. Cooran Lane, $140 \mathrm{~cm}$

$7541 \pm 120$

5591 в.c.

Blanket-bog peat from $140 \mathrm{~cm}$. Fluctuations in pollen curves and presence of charcoal fragments in peat suggest occurrence of a fire at this level.

Q-876. Loch Dungeon Peat, 125 cm

$7165 \pm 180$

5215 B.c.

Pine stump from $125 \mathrm{~cm}$ just beneath highly humified amorphous black layer which may be a fossil soil. Alt $1250 \mathrm{ft}\left(55^{\circ} 7^{\prime} \mathrm{N}\right.$ Lat, $4^{\circ} 19^{\prime}$ W Long, Nat. Grid. Ref. 25/5284).

Q-877. Loch Dungeon Peat

$6787 \pm 200$

4837 в.c.

Pure organic fossil mor humus soil assoc. with Q-876 pine wood.

Q-878. Clatteringshaws Loch, $87 \mathrm{~cm}$

$5080 \pm 100$

Pine stump at $87 \mathrm{~cm}$ depth in layer of wood peat. Alt $800 \mathrm{ft}\left(55^{\circ}\right.$ $4^{\prime} \mathrm{N}$ Lat, $4^{\circ} 17^{\prime} \mathrm{W}$ Long, Nat. Grid. Ref. 25/5477).

General Comment (H.H.B.): the dates show that the pine stumps are of 
different ages in the Eastern Highlands and the Galloway Hills and are of different ages within each of these areas. The relationship of the stumps to the pollen stratigraphy from each site is consistent with these results. From the available dates, and studies of local vegetational events by pollen analysis and peat stratigraphy, no climatic conclusions may be drawn from the occurrence of these pine stumps to support the BlyttSernander scheme of climatic periods.

\section{ARCHAEOLOGIC SAMPLES}

\section{Somerset Levels series, SW England}

Excavations of the prehistoric trackways of the Somerset Levels (Godwin, 1960) has been continued by J. M. Coles and his students from the Dept. of Archaeol. and Anthropol., University of Cambridge (Coles and Hibbert, 1968). The Sub-Dept. of Quaternary Research is also assoc. with the work through the participation of F. A. Hibbert who checked the peat stratigraphy and carried out pollen analyses, and through V. R. Switsur who made the radiocarbon analyses. The number of trackways discovered continues to grow and forms a veritable arterial road system between Westhay and Catcott Burtle, the oldest such system in Europe. Samples were coll. between August 1967 and September 1968 by Coles and Hibbert to obtain precise correlation between tracks in this area.

\section{Q-908. Abbot's Track Peat}

$3964 \pm 60$

Sphagnum-Eriophorum-Calluna peat underlying the Abbot's track, overlying layers of wood and fen peat $\left(51^{\circ} 7^{\prime}\right.$ Lat, $2^{\circ} 50^{\prime} \mathrm{W}$ Long, Nat. Grid Ref. ST 417427). This agrees very well with wood from the track itself (Q-926).

\section{Q-926. Abbot's Track Peg}

$4018 \pm 80$ 2068 B.c.

Wooden peg used to stabilize the track which lies in ombrogenous peat ca. $40 \mathrm{~m} \mathrm{~W}$ of Honeygore track (Q-909), and in a stratigraphically younger position in the peat $\left(51^{\circ} 11^{\prime} \mathrm{N}\right.$ Lat, $2^{\circ} 50^{\prime} \mathrm{W}$ Long, Nat. Grid Ref. ST 417427). Date agrees well with peat underlying the track (Q-908), and with other determinations of age of track (LU-298, $3940 \pm 65$; Gak$1950,4040 \pm 90)$. It does not agree, however, with our previous determination, Q-674, and we now disregard this date for technical reasons assoc. with its dating.

\section{Q-927. Bell Track 'A'}

$4570 \pm 80$

Birch stump rooted beneath Trackway 'A', severed during construction of the track, which should date the surface upon which it was lain (51 $11^{\prime} \mathrm{N}$ Lat, $2^{\circ} 50^{\prime} \mathrm{W}$ Long, Nat. Grid Ref. ST 428422). Date falls between those of the Abbot's and Honeygore, and agrees with its stratigraphic position. 
Q-909. Honeygore Trackway Peg

$4773 \pm 80$

Wooden peg from track in Sphagnum-Eriophorum-Calluna peat $\left(51^{\circ}\right.$ $10^{\prime} \mathrm{N}$ Lat, $2^{\circ} 50^{\prime} \mathrm{W}$ Long, Nat. Grid Ref. ST 417428), parallel to the Abbot's track but lower stratigraphically. Lund radiocarbon date for this track is $4760 \pm 65$ (LU-297) and our previous determination Q-431 was $4750 \pm 130$; they agree well but disagree with the Gakushuin date 5640 \pm 120 (Gak-1939) by ca. $1600 \mathrm{yr}$.

\section{Q-948. Morton, Fife}

$6735 \pm 180$ 4785 в.c.

Small sample of charcoal from Morton near Tayport, Fife, Scotland $\left(56^{\circ} 25^{\prime} \mathrm{N}\right.$ Lat, $2^{\circ} 52^{\prime} \mathrm{W}$ Long, Nat. Grid Ref. NO 467257), assoc. with hearths of Mesolithic occupation levels, in sands at depth 16 to 19 in. below grass, 8 to 11 in. below plough-disturbed soil. Sands rest on volcanic bluff overlooking Tentsmuir Sands at ca. 39' O.D. Archaeologic program concerns investigations of earliest traces of man in Scotland. This is earliest date for Mesolithic in Scotland. Morton contains the largest known stone industry and will probably serve as a type site. Coll. 1969 by J. M. Coles, Dept. of Archaeol. and Anthropol., Univ. of Cambridge.

\section{Q-950. Myrtos 1, Crete}

$3805 \pm 85$

1855 B.c.

Wood charcoal ( $35^{\circ} 00^{\prime} \mathrm{N}$ Lat, $25^{\circ} 36^{\prime} \mathrm{E}$ Long) from $0.5 \mathrm{~m}$ below surface in black burnt earth in a small room with stone walls on 3 sides and filled with large pottery store jars. Myrtos settlement belongs to Early Minoan II and is on the SW coast of Crete. Date is related to destruction of the settlement. Coll. 1968 by P. Warren, Dept. of Archaeol., Univ. of Durham.

\section{Q-953. Myrtos 2, Crete}

$4142 \pm 80$

Wood charcoal from a further room of settlement at on the natural bedrock in clayey, heavily burnt black arth 1 myrtos lying surface. Expected archaeol. date. Coll. by P. Warren.

\section{CHECK SAMPLES}

Q-970. Scaleby Moss, 176.5 to $178.5 \mathrm{~cm} \mathrm{~B}$

$7401 \pm 120$

5451 в.c.

A re-determination of Q-165 $(7432 \pm 350)$ of peat from Zone VI/ VIIa boundary.

\section{Q.971. Scaleby Moss, 178.5 to $180.5 \mathrm{~cm} \mathrm{~B}$}

A re-determination of Q-167 $(7361 \pm 146)$ of a $2 \mathrm{~cm}$ slice of peat just below previous sample. 


\section{Q-972. Scaleby Moss, 69.5 to $71.5 \mathrm{~cm} \mathrm{C}$}

$10,200 \pm 200$

8250 B.c.

A re-determination of $Q-152(10,160 \pm 193)$ of a $2 \mathrm{~cm}$ slice of coarse detritus mud just above Zone III/IV boundary. Above samples were measured before unknown samples were undertaken to compare performance of the new apparatus with known data.

\section{REFERENCES}

Birks, H. H., 1969, Studies in the vegetational history of Scotland: Ph.D. dissert., Univ. of Cambridge.

Coles, J. M. and Hibbert, F. A., 1968, Prehistoric roads and tracks in Somerset, England: 1, Neolithic: Prehist. Soc. Proc., v. 34, p. 238-258.

Godwin, Harry, 1960, Prehistoric wooden trackways in the Somerset Levels: their construction, age, and relation to climatic change: Prehist. Soc. Proc., v. 26, p. 1-36.

Godwin, Harry and Willis, E. H., 1959, Cambridge University natural radiocarbon measurements I: Am. Jour. Sci. Radiocarbon Supp., v. 1, p. 63-75.

1960, Cambridge University natural radiocarbon measurements II: Am. Jour. Sci. Radiocarbon Supp., v. 2, p. 62-72.

Godwin, Harry, Walker, Donald, and Willis, E. H., 1957, Radiocarbon dating and postglacial vegetational history: Scaleby Moss: Royal Soc. [London] Proc., ser. B, v. 147 , p. $352-366$.

Lewis, F. J., 1905-7, 1911, The plant remains in the Scottish peat mosses: Royal Soc. Edinburgh Trans., v. 41, p. $699-723$; v. 45 , p. $335-360$; v. 46, p. $33-70$; v. 47, p. 793-833.

Samuelson, G., 1910, Scottish peat mosses, a contribution to the knowledge of the late Quaternary vegetation and climate of the North-west Europe: Geol. Inst. Uppsala Bull., v. 10, p. 197-260. 